DOI: https://doi.org/10.36477/tourismhospcee-2-7

УДК 338.482

Свидрук I. I.

доктор економічних наук, професор, доцент кафедри менеджменту

Львівського торговельно-економічного університету

ORCID: https://orcid.org/0000-0002-3099-6449

Svydruk Irena

Lviv University of Trade and Economics

\title{
ДЕТЕРМІНАНТИ РАДИКАЛЬНИХ ІННОВАЦЙ У КЛАСТЕРНИХ УТВОРЕННЯХ КУЛЬТУРНОГО ТУРИЗМУ
}

\section{DETERMINANTS OF RADICAL INNOVATIONS IN CLUSTER FORMATIONS OF CULTURAL TOURISM}

\begin{abstract}
Статтю присвячено виокремленню детермінант радикальних інновацій підприємств в межах туристичних кластерів. Досліджено особливості географічної концентрації як чинника конкурентоспроможності та кластеризації-як ефективної моделі розвитку туристичних підприємств. Виявлено синергетичний ефект об'єднання зусиль окремих суб' сктів для зростання інноваційної активності туристичного кластеру. Проаналізовано географічну концентрацію суб' єктів та потенціал розвитку культурного туризму в Украйні. Описано чинники широкого впровадження радикальних інновачій з метою підвищення глобальної конкурентоспроможності. Виявлено значний негативний вплив структурного, незначний позитивнийреляційного та суттєвий позитивний - когнітивного сочіального капіталу на зростання інновацій, а також прямий незначний вплив сприйняття ринкової динамічності. Менеджерам підприємств рекомендовано включати в стратегічні плани прогнозні дослідження ринкового середовища. Подальші дослідження запропоновано зосередити на питаннях аналізу впливу розвитку людського капіталу та інституційного регулювання на технологічний прорив та поступові інновачії в галузі.
\end{abstract}

Ключові слова: туристичний кластер, культурний туризм, сочіальний капітал, конкурентоспроможність, синергетичний ефект, інноваційна активність.

Статья посвящена выделению детерминант радикальных инноваций предприятий в пределах туристических кластеров. Исследовань особенности географической концентрации как фактора конкурентоспособности и кластеризации - как эффективной модели развития туристических предприятий. Выявлен синергетический эффект объединения усилий отдельных субъектов для роста инновационной активности туристического кластера. Проанализированы географическая конџентраџия субъектов и потенциал развития культурного туризма в Украине. Описаны факторы широкого внедрения радикальных инноваций с целью повышения глобальной конкурентоспособности. Выявлено значительное негативное влияние структурного, незначительное положительное - реляционного и сущуественное положительное - когнитивного социального капитала на рост инноваций, а также прямое незначительное влияние восприятия рыночной динамичности. Менеджерам предприятий рекомендовано включать в стратегические планы прогнозные исследования рыночной среды. Дальнейшие исследования предложено сосредоточить на вопросах анализа влияния развития человеческого капитала и институционального регулирования на технологический прорыв и постепенные инновации в отрасли.

Ключевые слова: туристический кластер, культурный туризм, социиальный капитал, конкурентоспособность, синергетический эффект, инновационная активность.

The article is devoted to the identification of determinants of radical innovations of enterprises within tourism clusters and the study of the heterogeneous impact of social capital development on radical innovations. Peculiarities of geographical concentration as an alternative factor of competitiveness of enterprises of the tourist branch are investigated. Clustering has been identified as the most effective model of regional development, which contributes to the coordinated management of business development of independent entities in related industries. The synergetic effect of combining the efforts of individual entities to increase the innovative activity of the tourism cluster, which is especially relevant for Ukraine in a system of insufficient investment resources. The geographical concentration of cultural tourism entities in Ukraine is analyzed and four historically formed regions are singled out. The potential for the development of domestic cultural tourism in Ukraine is analyzed, in particular, the place of Ukrainian monuments in the UNESCO World Heritage List is shown. The factors of wide introduction of radical innovations for the purpose of increase of global competitiveness are described, in particular inclusion of the international standards in activity of the enterprises of service and rapid changes in tourist demand. The characteristic features of the tourist cluster due to the production specialization of the subjects of its formation are revealed. The structural, relational 
and cognitive dimensions of social capital as a relevant resource for competitiveness growth are analyzed. Hypotheses on the impact of these dimensions of social capital on the level of radical innovation of cultural tourism clusters are analyzed. Significant negative influence of structural, insignificant positive - relationnal and essential positive cognitive social capital on growth of innovations, and also direct insignificant influence of perception of market dynamics is revealed. Business managers are recommended to include in market plans forecast market research. Further research is proposed to focus on the analysis of the impact of human capital development and institutional regulation on technological breakthroughs and gradual innovations in the industry.

Keywords: tourist cluster, cultural tourism, social capital, competitiveness, synergetic effect, innovative activity.

Постановка проблеми. Управління підприємствами туристичної галузі часто розглядають як систему інструментів, спрямованих виключно на збільшення їх капіталізації. Такий підхід є доволі обмеженим, адже туризм є складною соціотехнічною структурою, розвиток якої обумовлюється багатосторонньою взаємодією 3 організаціями інших галузей. У цьому сенсі найбільш перспективною організацією розвитку галузі є кластеризація, за якої розвиток туристичних підприємств досконало узгоджується із ефективною діяльністю господарюючих суб'єктів інших галузей. Незважаючи на кризові явища 2020 р., викликані пандемічними обмеженнями, слід відзначити, що за останні роки туристична галузь зазнала значного зростання і може розглядатись як стратегічний сектор української економіки, забезпечуючи iii динамічне зростання завдяки інноваційності. Разом $з$ тим, роль і значення проривних інновацій в індустрії гостинності та туризму, зокрема у середовищі культурного туризму, до сьогодні все ще залишається недооціненою, що і послужило поштовхом до проведення нашого дослідження.

Аналіз останніх досліджень і публікацій. Зважаючи на важливість туристичної галузі для розвитку економічної системи України, різноманітні аспекти іï функціонування завжди були в центрі уваги багатьох вітчизняних науковців. Особливу цінність для нашого дослідження мають висновки економістів щодо кластерної організації розвитку галузі. Так, досліджуючи регіональні фактори ринкових переваг, О. Ольшанська та А. Мельник детально описують ті, що стосуються унікальності розміщених в регіонах рекреаційних ресурсів 3 точки зору їх інтеграції у розвиток виробничого та інфраструктурного потенціалу регіону, ринку його людських ресурсів, включення механізмів $\mathrm{i}$ моделей спільної взаємодії [2]. Продуктивність кластера автори об'єктивно пов'язують 3 поєднанням фінансових, матеріальних та інтелектуальних ресурсів, доступом до новітніх технологій, поліпшенням інфраструктурного обслуговування, підвищенням конкурентоспроможності на міжрегіональних і глобальних ринках тощо. Успішність залучення до кластерних утворень підприємств малого і середнього бізнесу дозволяе прискорити в їхньому середовищі обмін інформацією, технологіями, управлінським досвідом.

О. Стрішенець, О. Ляшенко зазначають, що попри проголошення про впровадження кластер- ної моделі розвитку економіки і включення формування й розвитку транскордонних кластерів до концепції національної стратегії, в українському законодавстві поняття кластеризації практично не відображено [6]. Науковий доробок авторів у даній царині свідчить про досягнення кластерного синергетичного ефекту для розвитку сфери туризму в регіональному масштабі завдяки близькості й тісний взаємодії учасників. Зокрема, основним завданням туристично-рекреаційної кластеризації вони вбачають стимулювання інвестиційної активності та регіонального підприємництва.

А. Охріменко доводить, що практично у всіх регіонах України існують належні умови для кластеризації пріоритетних галузей, виділяючи при цьому транскордонні регіони як особливо привабливі для кластеризації туристичної індустрії [3]. Автор відзначає такий драйвер іiї кластеризації, як конкуренція в регіональному та локальному виміpax. Конкурентні ресурси регіону він пропонує поєднувати в туризмі та сільському господарстві, у зеленому й науковому туризмі, у промисловому та діловому туризмі.

Аналізуючи інфраструктуру туристичних кластерів, Г. Саркісян звертає увагу на іiі розгалуженість і структурне об'єднання надавачів туристично-рекреаційних послуг, постачальників специфічних ресурсів, сервісного обслуговування, фінансових інститутів, організацій суміжних сфер діяльності, спеціалізованих провайдерів інфраструктурного забезпечення, наукових організацій, осередків по збору інформації, торгових асоціацій [5]. Попри те, що така розгалуженість видається нам дещо декларативною, розуміння автором системності туристичної кластеризації спонукало його до більш детального дослідження регіональної структури туристичного кластеру, що виявило комбінаторне поєднання системоутворюючих компонентів.

Високоінформативним для подальшого поглибленого аналізу є дослідження М. Назарук та Ю. Жук, присвячене концептуальним засадам туристичної кластеризації на рівні вже сформованих метрополій [1]. Висновок про ії̈ визначальність для забезпечення регіональної конкурентоспроможності видається нам цілком логічним 3 огляду на те, що саме кластеризація сприяе формуванню сприятливого підприємницького середовища, зростанню економічної активності суб'єктів господарювання, пришвидшує інноваційно-інвес- 
тиційні процеси. Отож, саме туристичні кластери варто розглядати в якості інструментів регулювання урбанізаційних процесів у регіоні та формування стійких метрополійних функцій.

Відзначимо, що вітчизняними науковцями все ще недостатньо розглядаються питання інноваційного розвитку кластерних утворень в індустрії гостинності та туризму. Разом з тим, до цієї проблеми сьогодні все частіше звертаються іноземні автори. Так, дослідження M. Ruiz-Ortega та ін. свідчать про зростання рівня інноваційної активності кластерно організованих підприємств туристичної галузі [16]. Водночас, автори наводять аргументи щодо неоднорідних можливостей у використання переваги економіки агломерації, що вимагає вивчення детермінант інноваційного розвитку окремих суб'єктів кластерного утворення.

Цікавим $є$ науковий доробок W. Dai та ін., які розглядали роль соціального капіталу як підгрунтя розвитку інновацій та досягнення конкурентоспроможності підприємств туристичній галузі. Автори відзначали його роль для координування управлінських та продуктових інновацій в кластерах культурного туризму, зумовлену здатністю бізнесу до виявлення інформаційної асиметрії [9], що відкриває можливості для розробки радикальних інновацій та сприяє використанню радикальних нововведень 3 наперед невизначеним результатом.

L. Kyrgidou тa S. Spyropoulou застерігають, що надмірне захоплення розвитком соціального капіталу може перешкодити радикальним інноваціям організацій через зростання ресурсних витрат [13]. Разом з тим, автори свідчать, що кластерна організація збільшує можливості генерації радикальних інновацій.

Хоча у науковій літературі звертання до інновацій в галузі гостинності та туризму є доволі поширеним, аналізу здебільшого піддаються питання описових характеристик, незалежно від того, чи це поступові зрушення, чи інновації радикального типу. Тому надзвичайно цінним видається аналіз, проведений J. Aarstad та ін., які зосередились на інноваціях у туристичних кластерах, орієнтованих на зростання привабливості нових туристичних напрямків у глобалізованій економіці, зокрема залежності конкурентних позицій кластерно організованих суб' єктів від ефективності радикальних інновацій [7]. Автори підкреслюють сприяння кластеризації для дифузії знань, що є критично важливим для запровадження радикальних інновацій, однак вказують на недостатній досвід інноваційної радикалізації підприємств індустрії гостинності та туризму.

Виділення невирішених раніше частин загальної проблеми. Як бачимо, досі нез'ясованими залишаються причини виникнення неоднорідність інновацій серед агломерованих підприємств індустрії гостинності та туризму, що спонукає нас до пошуку шляхів усунення даної прогалини, окреслення факторів взаємодії суб'єктів в кластерах культурного туризму, що спричиняють до інноваційного зрушення їх розвитку. На відміну від існуючих досліджень, в яких інновації зазвичай розглядаються в якості глобальних конструктів, ми вважаємо за доцільне виокремити детермінанти радикальних інновацій підприємств в межах туристичних кластерів та дослідити неоднорідний вплив розвитку соціального капіталу на радикальні інновації.

Постановка завдання. Метою дослідження $є$ аналіз зв'язку між вимірами соціального капіталу та радикальними інноваціями у кластерних утвореннях індустрії гостинності та туризму.

Виклад основного матеріалу дослідження. Традиційно вважається, що в умовах агресивної глобалізації лише великі компанії, використовуючи переваги масштабу та досвіду, здатні забезпечувати власні високі конкурентні позиції на ринку. Разом 3 тим, недостатньо уваги приділяється такому альтернативному чиннику конкурентоспроможності підприємств туристичної галузі, як географічна концентрація. Водночас, ще М. Porter зазначав, що у кластерних агломераціях переваги досягаються за рахунок географічної близькості та безперервної взаємодії між суб'єктами [14].

Кластерізація визначається сучасними науковцями як одна 3 найбільш ефективних моделей регіонального розвитку галузевих комплексів, оскільки вона дозволяє управляти узгодженим бізнес-розвитком незалежних суб'єктів в суміжних галузях (рис. 1).

Взаємозалежність членів кластерного утворення зумовлюється впливом зростання результативності діяльності кожного з них на безперервне створення передумов ефективності решти його учасників. Об'єднання зусиль, спрямованих на зростання потенціалу кожного суб'єкта туристичного кластеру спричиняє до зростання інноваційної активності, що особливо актуально для України в умовах системної недостатності інвестиційних ресурсів. Дифузія знань в межах кластерного об'єднання сприяє зростанню якості пропонованих туристичних послуг, а узгоджена економічна політика посилює конкурентні позиції кожного його учасника. Зауважимо, що за такої організації обмін інформацією щодо потреб в товарах, технологіях і послугах між постачальниками та виробниками значно полегшується завдяки єдності цілей технологічно пов'язаних підприємств. В межах кластеру спостерігається також феномен поширення позитивного впливу успішних економічних суб'єктів на партнерів і конкурентів [12], що сприяє посиленню конкурентних позицій як окремих суб'єктів, так i кластера в цілому.

Географічна концентрація суб'єктів культурного туризму в Україні дозволяє виділити чотири істо- 


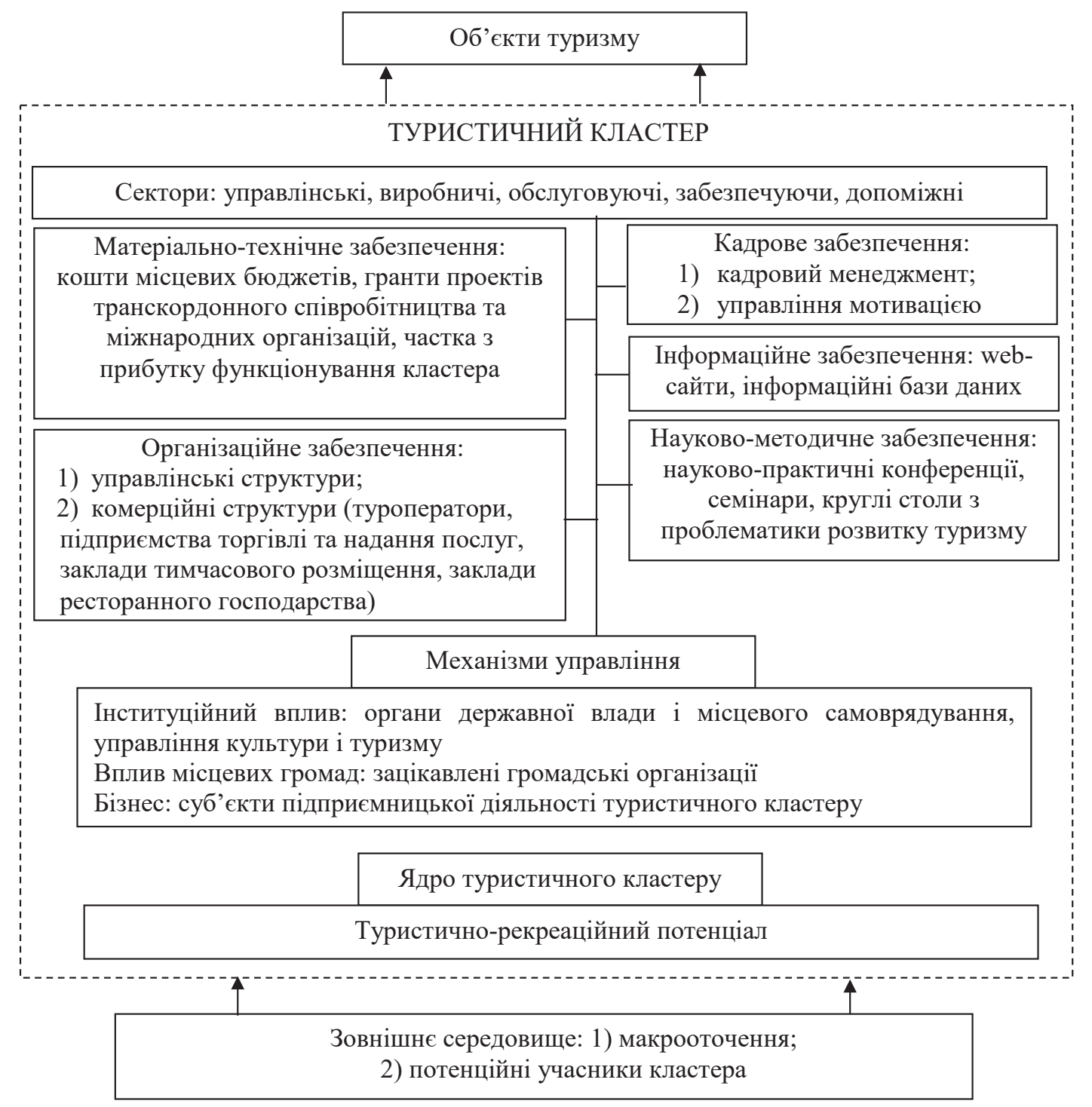

Рис. 1. Узагальнена структура туристичного кластеру

Джерело: побудовано за матеріалами [5]

рично сформовані регіони: Західний (Львівська, Івано-Франківська, Тернопільська, Чернівецька, Закарпатська, Волинська, Рівненська, Хмельницька області), Північний (м. Київ, Київська, Житомирська, Черкаська, Чернігівська, Вінницька, Кіровоградська області), Східний (Харківська, Сумська, Полтавська, Дніпропетровська, Запорізька, Донецька, Луганська області) та Південний (АР Крим, Херсонська, Миколаївська, Одеська області). Причиною значної переорієнтацією туристичних потоків після 2014 р. стала анексія АР Крим та військові дії в окремих районах Донецької і Луганської областей, що спричинили до значної втрати туристичних потоків. Достатню стабільність розвитку туризму демонструє Північний регіон, однак починаючи з 2017 р. за темпами розвитку лідером стабільно є Західний регіон [4].

Потенціал розвитку внутрішнього культурного туризму в Україні $є$ надзвичайно високим. Зокрема, на державному обліку перебуває 57,2 тис. пам'яток археології, 51,4 тис. - історії, 5,9 тис. - монументального мистецтва, 16,3 тис. - архітектурного та паркового мистецтва, 61 історико-культурний заповідник. До Списку всесвітньої спадщини ЮНЕСКО включено 7 об'єктів, що становить 0,6\% загальної кількості у світі (табл. 1).

Серед великих проектів культурного туризму в Україні варто відзначити Національний історикокультурний заповідник "Гетьманська столиця", Культурно-мистецький музейний комплекс "Мистецький Арсенал”, Національний заповідник “Хортиця”, Державну національно-культурну програму “Золота підкова Черкащини”. Водночас, слід зауважити, що історико-культурна спадщина використовується недостатньо. В історичних центрах переважають туристичні підприємства малого і середнього бізнесу, незалежних від транснаціональних туристичних корпорацій. Отож, це сприяє більш актив- 
Таблиця 1

Список пам'яток, включених до всесвітньої спадщини ЮНЕСКО

\begin{tabular}{|c|c|c|c|}
\hline Назва пам'ятки & Розташування пам'ятки & $\begin{array}{c}\text { Час } \\
\text { створення } \\
\text { пам'ятки }\end{array}$ & $\begin{array}{l}\text { Рік внесення } \\
\text { до списку }\end{array}$ \\
\hline \multicolumn{4}{|c|}{ Київ: собор святої Софії та прилеглі чернечі будівлі, Києво-Печерська лавра } \\
\hline Софійський собор & \multirow{3}{*}{ Київ } & 1037 & \multirow{3}{*}{$\begin{array}{c}1990 \\
\text { (зміни 2005) }\end{array}$} \\
\hline Києво-Печерська лавра & & 1051 & \\
\hline Церква Спаса на Берестові & & XII-XVII ст. & \\
\hline \multicolumn{4}{|c|}{ Львів - ансамбль історичного центру } \\
\hline Високий замок і Підзамче, Середмістя & \multirow{2}{*}{ Львів } & XIII-XVIII ст. & \multirow{2}{*}{$\begin{array}{c}1998 \\
\text { (зміни 2008) }\end{array}$} \\
\hline Ансамбль собору святого Юра & & $1744-1762$ & \\
\hline \multicolumn{4}{|c|}{ Геодезична дуга Струве } \\
\hline $\begin{array}{l}\text { Пункти геодезичної дуги Струве: } \\
\text { "Катеринівка", } \\
\text { "Фельштин", } \\
\text { "Баранівка" } \\
\text { "Старо-Некрасівка" }\end{array}$ & $\begin{array}{l}\text { Хмельницька обл. } \\
\text { Хмельницький, } \\
\text { Ярмолинецький р-ни } \\
\text { Одеська обл. } \\
\text { Ізмаїльський р-н } \\
\end{array}$ & $1816-1855$ & 2005 \\
\hline $\begin{array}{l}\text { Первісні букові ліси Карпат } \\
\text { та інших регіонів Європи: } \\
\text { Чорногора, Кузій - Трибушани, Мараморош, } \\
\text { Стужиця - Ужок, Свидовець, Уголька - Широкий } \\
\text { Луг, Горгани, Розточчя, Сатанівська дача, Синевир - } \\
\text { Дарвайка, Синевир -Квасовець, Синевир - } \\
\text { Стримба, Синевир - Вільшани, Зачарований край - } \\
\text { Іршавка, Зачарований край - Великий Діл }\end{array}$ & \begin{tabular}{|c|} 
Закарпатська обл. \\
Іршавський, Міжгірсьий, \\
Рахівський, Тячівський р-ни; \\
Івано-Франківська обл. \\
Надвірнянський р-н; \\
Львівська обл. \\
Яворівський р-н; \\
Хмельницька обл. \\
Городоцький р-н \\
\end{tabular} & - & $\begin{array}{c}2007 \\
\text { (розширено } \\
2011 \text { та 2017) }\end{array}$ \\
\hline Резиденція митрополитів Буковини та Далмації & Чернівці & $1864-1882$ & 2011 \\
\hline \multicolumn{4}{|c|}{ Дерев’яні церкви карпатського регіону в Польщі та Україні } \\
\hline Церква Святої Трійці & $\begin{array}{c}\text { Львівська обл. } \\
\text { м. Жовква }\end{array}$ & 1720 & \multirow{8}{*}{2013} \\
\hline Церква святого Юра & м. Дрогобич & 1502 & \\
\hline Церква Святого Духа & $\begin{array}{l}\text { Жовківський р-н } \\
\text { с. Потелич }\end{array}$ & 1502 & \\
\hline Церква Собору Пресвятої Богородиці & $\begin{array}{l}\text { Турківський р-н } \\
\text { с. Матків }\end{array}$ & 1838 & \\
\hline Церква Святого Духа & $\begin{array}{c}\text { Івано-Франківська обл. } \\
\text { м. Рогатин }\end{array}$ & 1598 & \\
\hline Церква Різдва Пресвятої Богородиці & $\begin{array}{l}\text { Коломийський р-н } \\
\text { с. Нижній Вербіж }\end{array}$ & 1808 & \\
\hline Вознесенська церква & $\begin{array}{c}\text { Закарпатська обл. } \\
\text { Рахівський р-н } \\
\text { селище Ясіня }\end{array}$ & XVI ст. & \\
\hline Церква святого Михайла & $\begin{array}{l}\text { Великоберезнянський р-н } \\
\text { с. Ужок } \\
\end{array}$ & 1745 & \\
\hline Стародавнє місто Херсонес Таврійський & Севастополь & \begin{tabular}{|c|} 
IV ст. до н. е. - \\
XII ст. н. е. \\
\end{tabular} & 2013 \\
\hline
\end{tabular}

Джерело: сформовано за даними [17]

ному розвитку співпраці між компаніями, в межах географічного кластера створюються стійкі структури співпраці, що може слугувати ключовим фактором для генерації інновацій в галузі.

В даний час глобалізація туристичної діяльності, включення міжнародних стандартів у діяльність підприємств обслуговування та стрімкі зміни в туристичному попиті генерують значну динамічність у цій галузі, що широкого впровадження радикальних інновацій $з$ метою підвищення гло- бальної конкурентоспроможності. Отож, дифузія знань та колективне навчання визначають успішність як інноваційних перетворень в межах підприємства, так і розвитку відповідної території. Не менш важливим фактором стимулювання інноваційної активності $є$ розвиток соціального капіталу, роль якого в туристичній галузі є традиційно недооціненою. Натомість ми вважаємо беззаперечно корисними можливості вбудовування управління соціальним капіталом в управлінську практику 
туристичних кластерних утворень саме через відкриття розширених можливостей для полегшення транспорту нових знань. У цьому сенсі, туристичні кластери виступають у ролі ефективного драйверу інновацій, оскільки дозволяють зменшувати трансакційні витрати на інновації, сприяють надходженню інвестицій для розвитку.

Аналіз наукових досліджень щодо агломераційних можливостей розвитку культурного туризму свідчить, що підприємства в структурі кластера, як правило, мають схожі ресурси, структури витрат, ментальні моделі та конкурентну поведінку, що забезпечує їм конкурентні переваги над спорідненими організаціями за межами кластеру $[11 ; 15]$. Характерною особливістю туристичного кластера є виробнича спеціалізація суб'єктів його утворення, що передбачає високий ступінь зв’язків: вертикальних - між туристичними підприємствами, їх постачальниками i дистриб'юторами та горизонтальних - 3 прямими конкурентами. Соціальний капітал, який генерується завдяки налагодженню міжорганізаційних зв'язків в кластері розглядається як достатньо релевантний ресурс для зростання конкурентоспроможності його суб'єктів. Аналізуючи соціальний капітал в кластерних утвореннях культурного туризму, варто виокремлювати його три виміри: структурний, реляційний та когнітивний.

Структурний соціальний капітал кластера співвідноситься із соціальною взаємодією між його суб'єктами, враховує особливості функціонування конкретного кластера. Реляційний соціальний капітал полягає у якості співвідношення між суб'єктами і включає характеристики та атрибути взаємовідносин із зовнішнім середовищем щодо налагодження відкритості, співпраці, прихильності та спільної ідентичності. Когнітивний соціальний капітал включає ресурси, набуті завдяки спільним цілям та загальною організаційною культурою різних суб'єктів кластера. За своєю суттю, це сукупність норм та інституціоналізованих правил розвитку кластера.

Отож, варто дослідити, яким чином розвиток соціального капіталу впливає на стимулювання радикальних інновацій. Розглядаючи вплив структурного соціального капіталу на інновації, ми висунули першу гіпотезу дослідження, про негативний характер впливу, спричинений надмірністю інформації в однорідних утвореннях, адже більшість туристичних підприємств в межах кластера користуються практично ідентичними базами знань, що унеможливлює набуття потенційних вигод від нового досвіду. Крім того, інерційність розвитку суб'єктів кластера спричиняє до певного обмеження пошуку нових знань поза агломерацією, а також гальмує передачу нових знань назовні, що спричиняє їх швидке старіння та обмежує можливості радикальних інновацій.
Разом 3 тим, складність формалізації і дифузіі скритих нових знань в межах кластера культурного туризму потребують розвитку комунікаційних інструментів. Отож, формування довіри, заснованої на чесності та відкритому спілкуванні, може сприяти полегшенню обміну інформацією і зростанню їі стратегічної цінності, що $\epsilon$ надзвичайно важливим фактором інноваційної активності. Отож, наша друга гіпотеза полягає в існуванні позитивного впливу реляційного соціального капіталу на радикальні інновації у кластерах культурного туризму.

Зосереджуючись на когнітивному вимірі соціального капіталу зазначимо, що у кластерах культурного туризму високий рівень пізнання та безпосередня близькість туристичних підприємств до об'єктів культурної спадщини забезпечує високу ефективність передачі інформації, мінімізує ймовірність виникнення культурологічних конфліктів. Крім того, це полегшує загальне розуміння колективних цілей та належного стратегічного курсу в межах соціальної системи, що дозволяє інтегрувати та поєднувати ресурси різних суб'єктів. Отож, третя гіпотеза нашого дослідження полягає в існуванні позитивного впливу когнітивного соціального капіталу на радикальні інновації підприємств, об'єднаних у кластерах культурного туризму.

Оскільки інноваційна активність бізнессуб'єктів зазвичай визначається комплексом внутрішніх i зовнішніх факторів, ринок можна розглядати в якості динамічного конкурентного середовища, в якому суб'єкти господарювання намагаються адаптувати власні стратегії до сприйнятих умов ринкових змін. Ми стверджуємо, що радикальні інновації, які полягають у розробці відповідних стратегічних змін, можуть забезпечити ефективну відповідь на високу динамічність ринку і створити нові можливості розвитку. Тому четвертою гіпотезою дослідження є власне наявність позитивного впливу сприйняття ринкової динамічності на радикальні інновації суб'єктів кластерів культурного туризму.

Для аналізу радикальних інновацій ми виокремлювали ті, які забезпечували повне або суттєве оновлення туристичного продукту, послуги чи організації діяльності. Для адекватного відбору інновацій було адаптовано шкалу, запропоновану D. Doloreux та R. Shearmur [10] для дослідженні технологічних i нетехнологічних інновацій підприємств сфери послуг. Такий підхід забезпечив охоплення новітніх підходів до туристичного продукту, виробничих процесів, бізнес-стратегій, управлінських та маркетингових процедур, здійснених підприєствами за останні 5 років. Для вимірювання рівні структурного, реляційного та когнітивного соціального капіталів ми використовували шкали Лайкерта (від 1 до 7). Сприйняття ринкового динамізму вимірю- 
Основні характеристики досліджуваних підприсмств в межах кластерів культурного туризму

\begin{tabular}{|l|c|c|}
\hline \multicolumn{1}{|c|}{ Змінні } & Середнс значення & Стандартне відхилення \\
\hline Розмір підприєства & 15,45 & 21,51 \\
\hline Вік підприємства & 17,88 & 19,25 \\
\hline Доступ до культурних ресурсів & 4,50 & 1,50 \\
\hline Доступ до капіталу & 2,52 & 1,63 \\
\hline \multicolumn{1}{|c|}{ Область } & Частота & Відсоток \\
\hline Київська & 32 & 14,9 \\
\hline Львівська & 29 & 13,5 \\
\hline Полтавська & 21 & 9,8 \\
\hline Миколаївська & 20 & 9,3 \\
\hline Чернівецька & 18 & 8,4 \\
\hline Харківська & 17 & 7,9 \\
\hline Івано-Франківська & 16 & 7,4 \\
\hline Ужгродська & 12 & 5,6 \\
\hline Дніпропетровська & 12 & 5,6 \\
\hline Херсонська & 12 & 5,6 \\
\hline Хмельницька & 11 & 5,1 \\
\hline Одеська & 9 & 4,2 \\
\hline Тернопільська & 6 & 2,8 \\
\hline \multicolumn{1}{|c|}{ Підсектор } & 215 & 100,0 \\
\hline & & \\
\hline Проживання (55) & 95 & 44,2 \\
\hline Їжа та напої (56) & 84 & 39,1 \\
\hline Транспорт (52) & 6 & 2,8 \\
\hline Туристичне обслуговування (59) & 8 & 3,7 \\
\hline Культура, мистецтво, рекреація (48) & 22 & 10,2 \\
\hline & Всього & 100,0 \\
\hline
\end{tabular}

Джерело: результати власного дослідження автора

вали за триелементною шкалою [8], що дозволило уніфікувати відомості про сприйняття менеджерами туристичних підприємств швидкості ринкових змін, пов'язаних із споживчим попитом, культурних уподобань споживачів та залучення нових клієнтів. В якості контрольних змінних було використано розмір та вік підприємства.

Нами було проаналізовано підприємства в межах кластерів культурного туризму, поділених за такими ознаками (табл. 2): послуги з розміщення (опитано менеджерів 55 підприємств), забезпечення продуктами харчування та напоями (56 підприємств), транспорту (52 підприємств), турфірм, туроператорів, служб бронювання та супутньої діяльності (59 підприємств), культурно-мистецького та рекреаційного характеру (48 підприємств).

Для оцінки запропонованих гіпотез моделі використано метод часткових найменших квадратів (МНК). Задача оцінювання МНК-параметрів $a_{1}, a_{2}, \ldots, a_{m}$ розв'язується шляхом параметричної оцінки функції регресії, що описує залежність величини $Y$, значення якої $\left(y_{i}\right)$ спостерігають 3 випадковими похибками $\left(\Theta_{i}\right)$, від групи невипадкових величин $x_{i 1}, x_{i 2}, \ldots x_{i k}$. Функція регресії - це функція $k$ змінних $x_{i 1}, x_{i 2}, \ldots x_{i k}$, яка $€$ математичним сподіванням величини $Y$. Оскільки проведені нами спостереження були нерівноточними, за оцінку параметрів рівняння взято значення, за яких сума $\mathrm{S}$ квадратів відхилень $\Theta_{i} \in$ мінімальною:

$$
S=\sum_{i=1}^{n} \Theta_{i}^{2}=\sum_{i=1}^{n}\left(y_{i}-f\left(x_{i 1}, x_{i 2}, \ldots x_{i k}, a_{1}, a_{2}, \ldots, a_{m}\right)\right)^{2} \text {, }
$$

Конвергентна та дискримінантна валідність розрахунків забезпечується перевищенням коефіцієнту комбінованої надійності (КН) отриманих показників мінімального порогу (табл. 3). $\mathrm{y}$ нашому випадку всі показники перевищують мінімальне значення 0,707.

Для підтвердження чи відхилення запропонованих гіпотез ми використали непараметричну техніку передискретизації. Результати аналізу ієрархічної регресії (табл. 4) демонструють ефекти впливу трьох вимірів соціального капіталу (гіпотези 1-3) та сприйняття ринкової динамічності (гіпотеза 4) на радикальні інновації суб'єктів кластерів культурного туризму.

Отож, структурний соціальний капітал виявляє значний негативний вплив на рівень радикальних інновацій $(y=-0,153 x+1,878 ; \mathrm{p}<0,05)$, отже гіпотезу 1 можна вважати підтверджено. Однак реля- 
Результати перевірки кореляційної матриці на валідність

\begin{tabular}{|l|c|c|c|c|c|c|c|c|c|c|c|c|c|}
\hline \multicolumn{1}{|c|}{ Параметри оцінювання } & $\mathbf{K H}$ & $\mathbf{S}$ & $\mathbf{1}$ & $\mathbf{2}$ & $\mathbf{3}$ & $\mathbf{4}$ & $\mathbf{5}$ & $\mathbf{6}$ & $\mathbf{7}$ & $\mathbf{8}$ & $\mathbf{9}$ & $\mathbf{1 0}$ & $\mathbf{1 1}$ \\
\hline 1. Сприйняття динамічності ринку & 0,9 & 0,7 & 0,8 & & & & & & & & & & \\
\hline 2. Структурний соціальний капітал & 0,9 & 0,8 & 0,2 & 0,9 & & & & & & & & & \\
\hline 3. Реляційний соціальний капітал & 0,9 & 0,6 & 0,2 & 0,7 & 0,9 & & & & & & & & \\
\hline 4. Когнітивний соціальний капітал & 0,9 & 0,8 & 0,3 & 0,5 & 0,7 & 0,9 & & & & & & & \\
\hline 5. Радикальні інновації & 1,0 & 0,7 & 0,2 & 0,1 & 0,2 & 0,3 & 0,9 & & & & & & \\
\hline 6. Розмір підприємства & - & - & 0,1 & 0 & 0 & 0,1 & 0,2 & 1,0 & & & & & \\
\hline 7. Вік підприємства & - & - & $-0,13$ & $-0,01$ & 0 & 0 & $-0,02$ & 0,2 & 1,0 & & & & \\
\hline 8. Розміщення кластера & - & - & & 0,1 & 0,1 & 0,1 & 0,1 & 0,1 & 0,1 & 1,0 & & & \\
\hline 9. Вид діяльності підприємства & - & - & $-0,04$ & 0,1 & 0,1 & 0,1 & 0 & $-0,13$ & 0 & 0,1 & 1,0 & & \\
\hline 10. Доступ до культурних ресурсів & 0,9 & 0,8 & 0 & 0,1 & 0 & 0,1 & 0,2 & 0,3 & 0 & $-0,01$ & 0 & 1,0 & \\
\hline 11. Доступ до капіталу & - & - & 0,2 & 0,3 & 0,3 & 0,4 & 0,5 & 0,2 & 0,1 & 0,1 & 0 & 0,1 & 0,9 \\
\hline
\end{tabular}

Примітка: у виділених комірках квадратний корінь $\mathrm{S}$

Джерело: результати власного дослідження автора

Таблиця 4

Результати регресійного аналізу впливу соціального капіталу та сприйняття ринкової динамічності на радикальні інновації суб'сктів кластерів культурного туризму

\begin{tabular}{|c|c|c|c|c|c|c|c|c|}
\hline \multirow{3}{*}{ Змінні } & \multirow{2}{*}{\multicolumn{2}{|c|}{ Гіпотеза 1}} & \multirow{2}{*}{\multicolumn{2}{|c|}{ Гіпотеза 2}} & \multirow{2}{*}{\multicolumn{2}{|c|}{ Гіпотеза 3}} & \multirow{2}{*}{\multicolumn{2}{|c|}{ Гіпотеза 4}} \\
\hline & & & & & & & & \\
\hline & $\beta$ & $t$ & $\beta$ & $t$ & $\beta$ & $t$ & $\beta$ & $t$ \\
\hline Розмір підприємства & 0,087 & 11,608 & 0,082 & 10,215 & 0,077 & 10,142 & 0,037 & 0,5446 \\
\hline Вік підприємства & $-0,046$ & 0,845 & $-0,037$ & 0,4748 & $-0,024$ & 0,3393 & $-0,009$ & 0,1333 \\
\hline \multicolumn{9}{|l|}{ Області: } \\
\hline Київська & $-0,059$ & 0,1178 & $-0,082$ & 0,1933 & $-0,093$ & 0,3243 & $-0,056$ & 0,1121 \\
\hline Львівська & 0,100 & 0,1695 & 0,058 & 0,1393 & 0,051 & 0,1756 & 0,070 & 0,1473 \\
\hline Полтавська & 0,035 & 0,0733 & 0,019 & 0,0753 & 0,016 & 0,0542 & 0,037 & 0,0884 \\
\hline Миколаївська & $-0,061$ & 0,0865 & $-0,068$ & 0,1447 & $-0,065$ & 0,1576 & $-0,037$ & 0,0627 \\
\hline Чернівецька & $-0,021$ & 0,0389 & $-0,048$ & 0,1364 & $-0,050$ & 0,2315 & $-0,026$ & 0,0644 \\
\hline Харківська & $-0,047$ & 0,0902 & $-0,046$ & 0,1169 & $-0,052$ & 0,1876 & $-0,007$ & 0,0147 \\
\hline Івано-Франківська & 0,021 & 0,0631 & $-0,010$ & 0,0306 & $-0,010$ & 0,0452 & 0,006 & 0,015 \\
\hline Ужгородська & $-0,025$ & 0,0543 & $-0,038$ & 0,0995 & $-0,036$ & 0,1194 & $-0,023$ & 0,0534 \\
\hline Дніпропетровська & 0,031 & 0,1076 & 0,014 & 0,052 & 0,007 & 0,0441 & 0,009 & 0,0299 \\
\hline Херсонська & 0,010 & 0,0162 & $-0,021$ & 0,0475 & $-0,028$ & 0,086 & 0,018 & 0,0358 \\
\hline Хмельниц & 0,017 & 0,0235 & $-0,002$ & 0,0031 & $-0,004$ & 0,0122 & 0,019 & 0,031 \\
\hline Одеська & $-0,076$ & 0,1934 & $-0,068$ & 0,2029 & $-0,070$ & 0,2677 & $-0,071$ & 0,1854 \\
\hline Тернопільська & $-0,039$ & 0,0825 & $-0,042$ & 0,1307 & $-0,038$ & 0,1842 & $-0,010$ & 0,0225 \\
\hline \multicolumn{9}{|l|}{ Підсектор: } \\
\hline Проживання (55) & 0,045 & 0,0037 & 0,017 & 0,0021 & 0,026 & 0,0025 & 0,025 & 0,0206 \\
\hline Їжа та напої (56) & 0,032 & 0,0015 & 0,002 & 0,0018 & 0,014 & 0,0011 & $-0,004$ & 0,0009 \\
\hline Транспорт (52) & $-0,036$ & 0,0026 & $-0,083$ & 0,0028 & $-0,070$ & 0,0025 & $-0,041$ & 0,0026 \\
\hline Туристичне обслуговування (59) & $-0,035$ & 0,0019 & $-0,073$ & 0,0023 & $-0,050$ & 0,0019 & $-0,016$ & 0,0022 \\
\hline $\begin{array}{l}\text { Культура, мистецтво, рекреація } \\
\text { (48) }\end{array}$ & 0,011 & 0,0007 & $-0,023$ & 0,0007 & $-0,005$ & 0,0007 & 0,018 & 0,0006 \\
\hline Доступ до культурних ресурсів & 0,387 & 5,7744 & 0,360 & 4,5653 & 0,350 & 5,18 & 0,328 & 3,5929 \\
\hline Доступ до капіталу & 0,094 & 1,2931 & 0,107 & 1,4387 & 0,109 & 1,4435 & 0,122 & 1,6198 \\
\hline Структурний соціальний к & $-0,153$ & & & & & & & \\
\hline Реляційний соціальний капітал & & & 0,097 & 0,898 & & & & \\
\hline Когнітивний соціальний капітал & & & & & 0,139 & 1,3721 & & \\
\hline Сприйняття динамічності ринку & & & & & & & 0,086 & 1,314 \\
\hline $\mathrm{R}^{2}$ & \multicolumn{2}{|c|}{0,293} & \multicolumn{2}{|c|}{0,317} & \multicolumn{2}{|c|}{$\frac{1}{0,322}$} & \multicolumn{2}{|c|}{0,365} \\
\hline
\end{tabular}

Примітка: $\mathrm{p}<0,05$.

Джерело: результати власного дослідження автора 
ційний соціальний капітал незначно впливає на радикальні інновації $(y=0,097 x+0,898 ; \mathrm{p}<0,05)$, тому гіпотезу 2 доцільно прийняти із застереженнями. Гіпотезу 3 доцільно прийняти, оскільки когнітивний соціальний капітал має позитивний вплив на радикальні інновації $(y=0,139 x+1,372$; $\mathrm{p}<0,05)$. Результати аналізу сприйняття ринкової динамічності демонструють прямий незначний вплив на радикальні інновації $(y=0,086 x+1,314$; $\mathrm{p}<0,05)$, тому гіпотеза 4 може вважатись умовно підтвердженою.

Висновки. Отримані результати свідчать, що структурний вимір соціального капіталу в середовищі кластерних утворень культурного туризму чинить суттєвий негативний вплив на рівень радикальних інновацій, який додатково посилюється із збільшенням сприйняття динамічності ринку. Міцні взаємозв'язки в межах кластера обмежують доступ до нової та унікальної інформації, що може перешкодити розвитку радикальних інновацій, особливо коли швидкі зміни в навколишньому середовищі сприймаються упереджено. Разом з тим, ефект останнього чинника не можна вважати критичним, оскільки сприйняття менеджерами швидких змін туристичного ринку включає інші механізми дифузії нових знань. Реляційний і когнітивний соціальний капітал чинять позитивний вплив різної сили на радикальні інновації. Наявність стійких взаємозв'язків в межах кластера може спричиняти до недостатнього моніторингу нових ідей в галузі культурного туризму, що актуалізує ризики недостатності доступу до нових потоків ідей, що може обмежити позитивний вплив когнітивного соціального капіталу на рівень радикальних інновацій. Однак слабкі позитивні ефекти посилюються завдяки достатньо високому сприйняттю ринкової динамічності. Таким чином, підприємства, об'єднані в туристичний кластер, отримують додаткові можливості інноваційного зростання завдяки своєчасній поінформованості про зміни культурного попиту клієнта та залученню нових споживачів у галузь. Сприйняття швидких динамічних змін зовнішнього середовища, в якому підприємства гостинності і туристичні організації отримують розширені можливості доступу до нових знань, сприяють передачі та обміну складно організованої та прихованої інформації. Отримані результати дозволяють стверджувати, що зростання ефективності комунікацій в межах кластерного утворення здатне посилити відклик його суб'єктів на потреби в радикальних інноваціях.

На основі отриманих результатів ми рекомендуємо менеджерам підприємств в структурі кластерних утворень культурного туризму здійснювати аналіз включення в стратегічні плани прогнозних змін ринкового середовища. Також вважаємо за доцільне рекомендувати до деякої міри обмежити конфіденційність суб'єктів, що дозволить підприємствам отримувати симетрично відкриті потоки інформації на зовнішніх ринках, сприяючи розвитку радикальних інновацій.

Перспективи подальших розвідок у напрямку інноваційного розвитку кластерних утворень культурного туризму вбачаються в аналізі ефектів впливу розвитку людського капіталу та інституційного регулювання на технологічний прорив та поступові інновації в галузі.

\section{Список використаних джерел:}

1. Назарук М., Жук Ю. Кластер туризму як складова функиіонування метрополї̈ м. Львова. Географія, економіка і туризм: національний та міжнародний досвід. Матеріали XIV Міжнародної наукової конференції (9 жовтня 2020 р., м. Львів). Львів : Львівський національний університет імені Івана Франка, 2020. С. $259-263$.

2. Ольшанська О. В., Мельник А. О. Регіональні туристичні кластери як важливий чинник економічного зростання. Формування ринкових відносин в Україні. 2017. № 12. С. 212-216.

3. Охріменко А. Г. Туристичні кластери як перспективні напрями регіонального розвитку. Університетські наукові записки. 2013. № 1(45). С. 495-500.

4. Романуха О. Тенденції розвитку культурно-пізнавального туризму в Україні в умовах глобалізаційних змін. Стратегічний потенціал державного та територіального розвитку. Матеріали III міжнародної науково-практичної конференції (Маріуполь, 9-10 жовтня 2019 р.). Маріуполь - Кривий Ріг : Донецький державний університет управління, 2019. С. 114-117.

5.Саркісян Г. О. Особливості формування регіональних туристичних кластерів. Наука, технології, інновації: світові тенденції та регіональний аспект. Матеріали III Міжнародної науково-практичної конференції (25-26 вересня 2020 р., м. Одеса). Одеса: ГО “Інститут інноваційної освіти”, 2020. С. 59-62.

6. Стрішенець О., Ляшенко О. Теоретичні аспекти туристичних кластерів як детермінант соціально-економічного розвитку регіону. Економічний часопис Східноєвропейського національного університету імені Лесі Українки. 2017. № 4(12). С. 7-12.

7. Aarstad J., Ness H., Haugland S. A. Innovation, uncertainty, and interfirmshortcut ties in a tourism destination context. Tour. Manage. 2015. Vol. 48. P. 354-361.

8. Atuahene-Gima K., Li H., De Luca L.M. The contingent value of marketingstrategy innovativeness for product development performance in Chinese newtechnology ventures. Ind. Mark. Manage. 2006. Vol. 35(3). P. 359-372.

9. Dai W., Mao Z., Zhao X., Mattila A.S. How does social capital influence thehospitality firm's financial performance? The moderating role ofentrepreneurial activities. Int. J. Hosp. Manage. 2015. Vol. 51. P. 42-55. 
10.Doloreux D., Shearmur R. Exploring and comparing innovation patternsacross different knowledge intensive business services. Econ. Innov. NewTechnol. 2010. Vol. 19(7). P. 605-625.

11.García-Villaverdea P. M., Elcheb D., Martínez-Pérezb Á., Ruiz-Hortegaa M. J. Determinants of radical innovation in clustered firms of the hospitality and tourism industry. International Journal of Hospitality Management. 2017. Vol. 61. P. 45-58.

12.Ilchyshyn S. M. Taxonomic analysis in the study of the possibilities of innovative development of trade in tourist and recreational zones. Innovative solutions in modern science. 2018. № 3(22). P. 5-19.

13.Kyrgidou L.P., Spyropoulou S. Drivers and performance outcomes ofinnovativeness: an empirical study. Br. J. Manage. 2013. Vol. 24. P. 281-298.

14.Porter M. Cluster and the economics of competition. Harv. Bus. Rev. 1998. Vol. 76. P. 77-91.

15.Rowley T., Behrens D., Krackhardt D. Redundant governance structures: ananalysis of structural and relational embeddedness in the steel and semiconductor industries. Strateg. Manage. J. 2000. Vol. 21(3). P. 369-386.

16.Ruiz-Ortega M. J., Parra-Requena G., García-Villaverde P.M. Do territorialagglomerations still provide competitive advantages? A study of social capital,innovation, and knowledge. Int. Reg. Sci. Rev. 2016. Vol. 39(3). P. 259-290.

17.UNESCO. World Heritage Sites in Ukraine. URL: http://whc.unesco.org/en/statesparties/ua (accessed 04 March 2021).

\section{References:}

1.Nazaruk, M., \& Zhuk, Yu. (2020). Klaster turyzmu yak skladova funktsionuvannia metropolii m. Lvova [Tourism cluster as a component of the functioning of the metropolis of Lviv]. Geography, economics and tourism: national and international experience. Proceedings of the XIV International Scientific Conference (October 9, 2020, Lviv). Lviv: Ivan Franko National University of Lviv, pp. 259-263.

2. Olshanska, O. V., \& Melnyk, A. O. (2017). Rehionalni turystychni klastery yak vazhlyvyi chynnyk ekonomichnoho zrostannia [Regional tourism clusters as an important factor of economic growth]. Formuvannia rynkovykh vidnosyn $v$ Ukraini, vol. 12, pp. 212-216.

3. Okhrimenko, A. H. (2013). Turystychni klastery yak perspektyvni napriamy rehionalnoho rozvytku [Tourist clusters as perspective directions of regional development]. University scientific notes, no. 1(45), pp. 495-500.

4. Romanukha, O. (2019). Tendentsii rozvytku kulturno-piznavalnoho turyzmu v Ukraini v umovakh hlobalizatsiinykh zmin [Trends in the development of cultural and cognitive tourism in Ukraine in the context of globalization]. Strategic potential of state and territorial development. Proceedings of the III International Scientific and Practical Conference (Mariupol, October 9-10, 2019). Mariupol - Kryvyi Rih: Donetsk State University of Management, pp. 114-117.

5. Sarkisian, H. O. (2020). Osoblyvosti formuvannia rehionalnykh turystychnykh klasteriv [Features of formation of regional tourist clusters]. Science, technology, innovation: global trends and regional aspect. Proceedings of the III International Scientific and Practical Conference (September 25-26, 2020, Odessa). Odessa: NGO "Institute of Innovative Education", pp. 59-62.

6. Strishenez, O., \& Lyashenko, O. (2017). Teoretychni aspekty turystychnykh klasteriv yak determinant sotsialno-ekonomichnoho rozvytku rehionu [Theoretical aspects of tourism clusters as a determinant of socio-economic development of the region]. Economic journal of Lesia Ukrainka Eastern European National University, no. 4(12), pp. 7-12.

7. Aarstad, J., Ness, H., \& Haugland, S. A. (2015). Innovation, uncertainty, and interfirmshortcut ties in a tourism destination context. Tour. Manage, vol. 48, pp. 354-361.

8. Atuahene-Gima, K., Li, H., \& De Luca, L. M. (2006). The contingent value of marketingstrategy innovativeness for product development performance in Chinese newtechnology ventures. Ind. Mark. Manage, vol. 35(3), pp. 359-372.

9. Dai, W., Mao, Z., Zhao, X., \& Mattila, A. S. (2015). How does social capital influence thehospitality firm's financial performance? The moderating role ofentrepreneurial activities. Int. J. Hosp. Manage, vol. 51, pp. 42-55.

10.Doloreux, D., \& Shearmur, R. (2010). Exploring and comparing innovation patternsacross different knowledge intensive business services. Econ. Innov. New Technol, vol. 19(7), pp. 605-625.

11. García-Villaverdea P. M., Elcheb D., Martínez-Pérezb Á., \& Ruiz-Hortegaa M. J. (2017). Determinants of radical innovation in clustered firms of the hospitality and tourism industry. International Journal of Hospitality Management, vol. 61 , pp. $45-58$.

12.Ilchyshyn, S. M. (2018). Taxonomic analysis in the study of the possibilities of innovative development of trade in tourist and recreational zones. Innovative solutions in modern science, no. 3(22), pp. 5-19.

13.Kyrgidou, L.P., \& Spyropoulou, S. (2013). Drivers and performance outcomes ofinnovativeness: an empirical study. Br. J. Manage, vol. 24, pp. 281-298.

14.Porter, M. (1998). Cluster and the economics of competition. Harv. Bus. Rev, vol. 76, pp. 77-91.

15.Rowley, T., Behrens, D., \& Krackhardt, D. (2000). Redundant governance structures: ananalysis of structural and relational embeddedness in the steel and semiconductor industries. Strateg. Manage. J, vol. 21(3), pp. 369-386.

16.Ruiz-Ortega, M.J., Parra-Requena, G., \& García-Villaverde, P.M. (2016). Do territorial agglomerations still provide competitive advantages? A study of social capital, innovation, and knowledge. Int. Reg. Sci. Rev, vol. 39(3), pp. 259-290.

17. UNESCO. World Heritage Sites in Ukraine. URL: http://whc.unesco.org/en/statesparties/ua (accessed 04 March 2021). 